\title{
THE EFFECTS OF TECHNOLOGY ON PEER RELATIONSHIPS AND INTERPERSONAL UNDERSTANDING: A CASE STUDY AT A TEACHER EDUCATION INSTITUTE IN MALAYSIA
}

\author{
RAMESH SATHAPPAN \\ (Department of Languages, \\ Institut Pendidikan Guru Temenggong Ibrahim, Malaysia) \\ E-mail: jhnmesh@yahoo.com \\ Malini Sathappan \\ (Corresponding author) \\ (Department of Professional Development and Continuing Education, \\ Faculty of Education Studies, Universiti Putra Malaysia) \\ E-mail: malinisathappan@yahoo.com
}

\begin{abstract}
In this information age, technology such as the internet has a profound effect on the peer relationships and interpersonal understanding. The study incorporates the views of authors on the subject. There are advantages and disadvantages in using electronic communication for interpersonal understanding. It promotes better understanding, cooperation and closer peer relationship among students and teens. However, it also has a darker side. It can lead to cyberbullying. Information and communication technology has transformed the classroom scenario by the use of videos, etc. in the teaching and learning process. Students have become more sophisticated in applying electronic devices for their academic performance. The findings show that majority of the students prefer to use e-mail in their interaction. It is recommended that teachers and parents monitor the students to ensure there is no abuse and misuse of technology.
\end{abstract}

Keywords: Effects of technology; peer relationship; interpersonal understanding, cyberbullying, information and communication technology

\section{Academic Discipline}

Social Science

\section{Sub-Disciplines}

Education

\section{Subject Classification}

Educational Psychology

\section{Type}

Survey/Interview

\section{Introduction}

Computer related technologies began to make inroads and are changing the concept of time and space rapidly. Technology's capacity to reach learners in any place and at any time has the potential to promote revolutionary changes in the educational paradigm. The diversity of needs and settings requires a diversity of means. Here is where learning technologies may provide their most valuable contribution. They are flexible, unconstrained by time and place, can be used on demand and provide just-in-time education. This may be the first time in the history of the human race when lifelong learning is not desirable and urgent but flexible as well.

The impact of information and communication technologies is not only confined to the field of education but also has influenced social development positively. Economic well-being has made it affordable to students and teens to possess laptops and smart phones. Children can easily contact their friends inside and outside school hours. Peer relationships begin at school and continues into adult life. This promotes interpersonal understanding.

This study elaborates on the types of information technology available and examines their effect on peer relationships and interpersonal understanding among students. It further discusses on the beneficial and adverse effects of electronic communication among students and teens. It concludes with the results of the research conducted in an educational institution and recommendations for teachers and parents.

\section{Background of the Study}

This study was conducted at a Teacher Education Institute in Malaysia. It involves a group of 20 undergraduate students. These are final year students currently pursuing a degree course in English as a Second Language (TESL). They belong to the age group of 20 years i.e. young adults. 
The purpose was to investigate the effects of technology on peer relationships and interpersonal understanding. The criteria for choosing them for this study are that they are matured, knowledgeble, co-operative and supportive. Moreover, they serve as a good sample to represent the peer group.

\section{Research Objective}

The aim of the study is:

1. To find out the view of peer relationships in interpersonal understanding

2. To find out the types of technology used by students

3. To find out the effects of technology in their personal life

4. To find out how technology has affected their relationship with their peers.

\section{Literature Review}

The introduction of cell-phone technology and software has made friendly relationship closer. It does not require specific space or time to communicate. Communication can take place anywhere and at anytime by using mobile phones. It is easier and faster to contact friends. Moreover the conversations can be private and confidential. There are different peer groups and each group has its own characteristics. There is a co-relation between a specific peer group and its characteristics. For instance, the teen-age group. Adolescence is a turbulent period. This is the time when the individuals cannot be classified neither as children nor as adults. Their psychical, emotional and social development undergoes changes. They begin to question the values they upheld hitherto. They get closer to their peers and peer influence seems to be greater than that of the parents.

\subsection{Friendships, larger social groups, cliques, crowds and gangs}

Researchers have expressed their views on the characteristics of peer relationships. The peer groups can be classified as friends, larger social groups, cliques, crowds and gangs. Peer relationships, especially friendships, serve at least three unique functions in children's and adolescents' personal and social development. They provide an arena for learning and practicing a variety of social skills, including cooperation, negotiation, emotional control and conflict resolution (J.P Allen \& Antonishak, 2008; Coplan \& Arbeau, 2009); Larson \& Brown, 2007). In addition, peers provide companionship, safety and emotional support. They become a group of whom to eat lunch, a safe haven from playground bullies and shoulders to cry on in times of trouble or confusion (Jordan, 2006; Laursen, Bukowski, Aunola \& Nurmi, 2007; Wentzel, 2009). Many adolescents revel their innermost thoughts and feelings to their friends (Levitt, Guacci-Franco \& Levitt, 1993; Patrick et al., 2002; A.J. Rose, 2002).

Peers serve as socialization agents that help to mould children's behaviors and beliefs (B.B. Brown, Bakken, Ameringer \& Mahon, 2008; A.M. Ryan, 2000). For example, they define options for leisure time. They serve as role models and provide standards for acceptable behavior, showing what's possible and what's admirable. Peer pressure has its greatest effects during early adolescence, with teenagers who have weak emotional bonds to their families being especially susceptible (Berndt, Laychak \& Park 1990; Erwin, 1993; Urdan \& Maehr, 1995). A common misconception is that peer pressure is invariably a bad thing. Many peers encourage such desirable qualities such as working hard, etc. Others, however, encourage negative behaviour (Mayeux, Houser \& Dyches, 2011).

Although peer pressure certainly is a factor affecting development, its overall influence on childern's behaviour has probably been overrated. Most children acquire a strong set of values and behavioural standards from their families and they don't necessarily abandon these values and standards in the company of their peers (B.B. Brown, 1990). Close friends find activities that are mutually meaningful and enjoyable and over time they acquire a common set of experiences that enable them to share certain perspectives of life. Friends work hard to look at situations from one another's point of view and to resolve disputes that threaten to separate them (Basinger, Gibbs, \& Fuller 1995). With age and experience, many students form larger social groups that frequently get together. In early adolescence, cliques provide the setting for most voluntary social interactions (B.B. Brown, 2011). Crowds are considerably larger than cliques and don't have the thight-knit cohesiveness and carefully drawn boundaries of cliques (Steinberg, 1996). Occasionally a crowd takes the form of a subculture, a group that resists a powerful dominant culture by adopting a significantly different lifestyle (J.S. Epste in, 1998). However, a gang is a cohesive social group characterized by initiation rites, distinctive colours and symbols. Gangs are governed by specific rules for behavior and stiff penalties for violations. Adolescents join gangs for a variety of reasons such as demonstrating loyalty to their family or friends. Many members of the gangs have troubled relationships with their families and so they turn to gangs to get emotional support (Dishion, Piehler \& Myers, 2008).

\subsection{Technology and peer relationships}

Modern information and communication technology has contributed a lot towards promoting peer relationships. Adolescents as well as adults are fond of using the Internet and e-mail for they are easily accessible, fashionable and cost-effective. Electronic communication does not require specific place and time. So, it has many benefits for those who communicate frequently. However, there are some disadvantages in using the Internet, Facebook etc. Children could be easily lured into undesirable activities.

The following discussion presents the pros and cons of using technology in peer relationships and interpersonal understanding. With the advent of cell telephone technology, text-messaging software and easy access to the Internet, many students now communicate quite frequently with some of their peers (Crosnoe, 2011). For example, e-mail allow 
quick and easy ways of asking friends about home work. Networking sites (i.e., facebook, myspace) could be used to share personal information. Internet-based chat rooms allo group discussions about any topic. At the same time, wireless technologies and Internet also provide vehicles for cyberbullying (electronically transmitting hostile messages and broadcasting personally embarassing information (Shariff, 2008). Cyberbullying can be more harmful than face-to-face bullying because prepetrators often remain anonymous (Kowalski\& Limber, 2007).

As children grow older, they understand their own and others' thoughts, beliefs, feelings and motives. As they mature, they gain experience and knowledge. This enables them to interact with their peers effectively. The development is an on-going process. However, there are three distinct periods: childhood, early adolescence and late adolescence during which changes in peer relationships take place. Childhood is consistent with what we know about cognitive development. Young children tend to focus on other people's concrete, observable characteristics and behaviors. They also have some ability to make inferences about other people's mental and emotional states. During early adolescence, most young adolescents realize that people can have mixed feelings about events and other individuals (Donaldson \& Westerman, 1986). Owing to their expanding cognitive abilities, memory capacity and social awareness, young adolescents become capable of recuirsive thinking (Oppenheimer, 1986). Late adolescence is the period where teenagers become even more skillful at drawing inferences about people's psychological characteristics and needs (Eisenberg, Carlo, Murphy \& Van Court, 1995).

\subsection{Paradigm shift}

The classroom scenario now has changed. Traditional methods of 'chalk and talk' has faded. Teachers use sophisticated methods to deliver their lessons. Technologies like video have made the teacher's presentation more interesting. Computer education in schools has enabled the students to gather information from different sources with ease. Group studies have promoted co-operation and interpersonal understanding inside and outside school. Mobile phones are very popular among students and teens. They facilitate exchange of views in academic as well as personal matters in privacy. So, electronic communication has transformed the traditional teaching methods into technology based ones. The result is closer peer relationships.

During the last ten to fifteen years, the situation has changed dramatically. Most of the recent research on the use of information and communication technology in education is more or less explicitly considering technology's possibilities to facilitate social interaction between teacher and students, and among students. Collaboration and communication is certainly a main idea in network-based learning environments, but social interaction has also been increasingly taken into consideration in the design and implementation of systems running in separate workstations (Crook, 1994; Lehtinen et al., 1999).

Most of the resent research of the use of information and communication technology in education more or less explicitly consideres technology's possibilities to facilitate social interaction between teacher and students and among students (Koschmann, 1996; Koschmann, Hall \& Miyake, 2002; Kumpulainen \& Wray, 2002, Lehtinen et al., 1999). Crook (1994) has widely alalysed how computers can facilitate colloborative learning in schools. He makes a distinction between interacting around and through computers. The first perspective stresses the use of computers as a tool to facilitate faceto-face communication between student pairs or in small group. According to Crook (1994) technology may, in these situations, serve to support collaboration by providing students with something he calls points of shared reference. He claims that a traditional classroom situation is too thinly resourced for successful collaboration. There are not enough anchor points available at which action and attention can be co-ordinated. The capabilities of computers can be used as mediating tools that help students to focus their attention to mutually shared objects (Jarvela, Bonk, Lehtinen \& Lehti, 1999).

Boyd and Ellison (2007) defined social network sites as public web-based services that allow users to develop a personal profile, identify other users ("friends") with whome they have a connection, read and react to postings made by other users on the site, and send and receive messages either privately or publicly. Idividuals may choose to send private messages, write on other user's walls, organize social activities, and keep informed about other user's daily activities. However, users can limit themselves on what information they would like to share publicly with others. Some items they may choose to influence are: pictures, favoirite books and movies, birthday, relationship status and location (Tufekci, 2008).

Baym, Zhang and Lin (2004) studied social interactions of college students across all media. Their results indicated that $64 \%$ still prefer face-to-face interaction, $18.4 \%$ prefer the telephone and only $16.1 \%$ prefer the internet for making social contacts. The internet interactions reported showed that e-mails was by far the most dominant form of contact, followed by chat and instant-messaging (Baym et al., 2004). Of the 51 participants in the study, 49 reported conducting their social life contacts through at least two, and often three, methods on any given day (Baym et al., 2004). Similarly, one study reported that over $27 \%$ of young adults used a social networking site every day in 2009 (Lenhart, Purcell, Smith \& Zickuhr, 2010).

Social network sites help fulfill communication needs and wants. It is a convenient method of communication and provides the ability to stay connected with friends and family, but on the users own rate and time (Urista, Dong \& Day, 2009). Users can manage their interactions within their own schedule by choosing when they want to read and respond. The internet communication is a solitary activity usually done alone. However, it is efficient because it is a one-to-many method of communication that allows users to quickly spread information. Social media fulfills different communication needs for different users. Interactions via the computer facilitate communication by allowing users to keep in touch with family and friends in a convinient way, to learn about social events, and to find out about activities of other users. The gratification received from this social information helped users feel that they were a part of a peer network of knowing what was going on about events and activities (Quan-Haase et al., 2010). 
Immediate communication benefits of Facebook users were seen for individuals reporting various levels of shyness. Shyness might cause individuals to avoid social, face-to-face interaction altogether, so these persons would have less communication and less social support. In a study looking at the assciation between online social media and friendship quiality of shy individuals, results indicated that online social networks provided a comfortable environment in which shy individuals could interact with others (Baker \& Oswald, 2010). Further, "social grooming" was an aspect of social networking that has received attention in a comparison of users and non-users of social media sites. Social grooming included expressive activities of social interaction, communication, gossip and entertainment. Users have expressed enjoyment from keeping track of their friends' lives and activities, but non-users were less interested in these activities (Tufekci, 2008). This social interaction of users may make it easier to communicate with others by keeping in touch with friends and family on a regular basis more often than non-users. Perceived communication was reported as being more satisfying in same-sex relationships rather than in cross-sex relationships (Baym et al., 2007). This was true for both woman-to-woman and man-to-man interactions. It is also not surprising that communication relationships were more satisfying with friends and family rather than with mere acquaintances (Baym et al., 2007).

Since social media provides an easy way to receive feedback and communicate with peers, young adults attitudes of themselves can be affected by using social media networks (Pempek et al., 2009). Social media sites empower users to take an active role in their own socialization process and in constructing their own self-identity (Urista et al., 2009). A personal profile is the way users present themselves; they can include as much information as desired about themselves, including posting pictures. Due to digital technology, users can show considerable information about themselves and their friends. This self-disclosure is a way to open up their own identities of how they want others to perceive them (Pempek et al., 2009). Intimate self-disclosures help produce greater intimacy in computer-mediated communication. In the HomeNet study, teenagers are more likely to help their parents with computers than parents were to help their children, with boys disproportionately helping their fathers any girls disproportionately helping their mothers (Keisler, Lundmark, Zdaniuk, Kraut, Scherlis \& Mukhopadhyay, 1998).

Research fron the HomeNet study indicates that in households with access to the Internet, use of the computer to communicate with others (via e-mail, chat rooms, etc.) is an increasingly popular activity especially among teens. Teens agreed that after doing homework, use of e-mail and participating in chat rooms were their most frequent activities on the Internet (Turow, 1999). Similarly, teenagers in the HomeNet sample reported that keeping up with both local and distant friends was a very important use of the Internet for them. Interpersonal communication via e-mail were more important to them than information acquisition via the web. Many of the keep-in-touch communications described by teens involved small talk - gossip and news of the day. These communications exist for the pleasure they bring, rather than for their instrumental benefits. A teenage girl, who was keeping up with a pen pal she met online, described the small-talk nature of her conversation with him as "stupid stuff-what's happening in his life; what's happening in my life."

The popularity of using Internet for interpersonal communication also sustained interest longer than other types of activities - that is, use of e-mail dropped less over the first 2 years online than did other uses of the Internet, such as linking to web sites. Teens and adults who used e-mail more heavily than they used the web were more likely to still be using the Internet after their first year. These observations suggest that e-mail is the primary Internet application keeps both teens and adults coming back to the computer (Turow, 1999). Although it is clear that the Internet is frequently used for social purposes by teens, it is not immediately obvious whether these social uses add to or diminish teenagers' stock of social resource. The influence depends in part on whether the social uses of the Internet suppliment or substitute for other source of social contact than teens have. Some research analyses focusing on the Internet have demonstrated that use of the computer is associated with declines in social involvement. Playing violent computer games could increase aggressive behavior and decrease prosocial behavior, continued exposure to violence and aggression in computer games may also desensitize children violence (Rule \& Ferguson, 1986).

Although playing specific computer games has immediate positive effects on specific spatial, iconic and attentional skills used by the game, we need more research to see if long term computer and Internet use can lead to long term improvement in cognitive skills and academic involvement. Also, we need further research to understand the cognitive and social effects of the newer generation of video games and other software, especially the multiuser games now available on the Internet. While mush of the time on computers is spent alone, moderate computer use does not negatively impact children's social skills and activities. On the contrary, e-mail and the Internet may actually help maintain interpersonal communication and sustain social relationships. However, we need to determine the impact of excessive computer and Internet use on children and adolescents' loneliness, social relationships and psychological well-being.

\subsection{Cyberbullying}

Technology can also be used for harmful purposes. Teens are exposed to environmental influences. Students develop friendships as well as face hostilities and strained relationships. Some teenagers who are social misfits resort to cyberbullying. Definitions of cyberbullying vary, but most researchers agree that it is an intentional, repeated and aggressive act or behavior carried out by a group or individual employing information and technology (ICT) as an instrument. The acts go against a victim who cannot easily defend him or herself or terminate the bullying (Smith et al., 2008; Vandebosch \& Van Cleemput, 2008; Wolak, Mitchell \& Finkelhor, 2007). While cyberbullying has many similarities with traditional bullying, the issues of repetition and power imbalance are less easy to define, as for example an embarassing picture, once uploaded to a website, can be viewed repeatedly, therby creating ongoing humilation. As to power imbalance, many cybervictims experience helplessness if their bully remains anonymous and often there is no getting away from cyberbullying, as technlogy based interactions can take place any time and in any place (Dooley, Pyzalski \& Cross, 2009; Slonje \& Smith, 2008). Another aspect distinguishing cyberbullying is anonymity, with cyberbullies able to remain unidentified behind their computer screen or cell phone and to agress against their victims even when they 
are physically far away (Spears, Slee, Owens \& Jhonson, 2009). This phsycal distance may help to disinhibit cyberbullies, making it easier to say or write things they normally would not in a face face-to-face interaction. So, technology allows potential bullies to distance themselves from their victims and disperse harmful material to a larger audience than ever before (Patchin \& Hinduja, 2011).

Cyberbullying is bullying via the use of internet, mobile phone or a combination of both and the modes chosen have diversified (i.e. bullying by phone call, text messages, instant messaging, e-mails, posting or sending embarassing photos or video clips, creating 'hate websites'). In order to intervene successfully, it is important that school personnel know about the different forms cyberbullying may take. Willare (2007) has offered an alternative classification according to the cyberbullying action itself, independent of the medium employed. She described 'flaming' which includes heated arguments through e-mails, or in chat rooms, during which rude, offensive or threatening messages are relayed. 'Harassement' implies repeatedly sending insulting, hurtful messages, while 'cyberstalking' involves consistent harassment and threats of phsycal harm, to a degree that the victim starts fearing for his or her safety. "Denigration' is posting mean, untrue or harmful material (text, photos or videos) about or of someone in order to harm his or herreputation, damage friendships or to humilate. During 'impersonation', another's identity is used to send or post material of insulting, imappropriate or embarassing content in ordre to damage the reputation or the friendships of the target. "Outing" is forwarding or publicly posting personal information or images of someone else, especially such material containing private, potentially embarassing information. "trickery" can be a part of outing, occuring when a person is tricked into revealing private, potentially embarassing information, believing that this is intended for the recepient only, while the cyberbullying intends to share the material with others. "Exclusion" occurs when someone is intentionally left out or barred from an online group or community.

Rather than considering cyberbullying as a separate phenomenon, it has become another form of bullying. Bullying behaviors may be directed as a target (i.e. hitting, kicking, name calling, swearing) or involve the peer group to indirectly target another student (i.e. gossiping, excluding) (Bjorkqvist, Lagerspetz \& Kaukiainen, 1992). Cyberbullying is another indirect form wherby the aggressor does not harass in a face-to-face interaction, but rather through an interface (computer screen, phone). Just as school bullying behaviours are likely to be witenessed by peers, harassing messages posted online are in a public domain and can be viewed by acquaintances and strangers. For these reasons, it seems likely that bullying at school is related to bullying on-line. The link between school bullying and cyberbullying can be conceptualized using social rank theory. This theory posits that peer group becomes established as a hierarchy whereby some students use aggression to dominate their peers as a means of gaining prestige, power, and access to resources (Espelage \& Swearer, 2003; Pellegrini \& Long, 2002). When peers submit to these dominant initiations by crying or feeling intimidated, power and control are exerted over them, which may be maintained over the long term (Sharp, Thompson \& Arora, 2000). Consequently, a child who submits to attacks at school may be at risk of experiencing additional bullying in cyberspace, which can persist over time and in settings outside the school. It is also possible that children who are bullied at school may attempt to retialiate through technology. This form of bullying may be less anxiety-provoking than face-to-face attacks, so victimised children may resort to this behaviour as a means of self-protection. Indeed, they may engage in bullying particularly if they are severely affected by it.

\section{Research Methodology}

The study was conducted at a Teacher Education Institute in Malaysia. The sample size consisted of 20 students from whom were 14 females and 6 males. Questionnaire and interview were the methods used to find out the effect of techonology on peer relationships and interpersonal understanding.

\section{Findings and Discussion}

\subsection{Communication with family and friends}

\section{Table 1.0 Communication with family and friends}

1 = strongly disagree $2=$ Disagree $3=$ Neutral $4=$ Agree $5=$ Strongly Agree

\begin{tabular}{|l|l|c|c|c|c|c|}
\hline NO & \multicolumn{1}{|c|}{ RESEARCH STATEMENT } & \multicolumn{3}{|c|}{ SCALE (\%) } \\
\cline { 4 - 6 } & \multicolumn{1}{|c|}{$\mathbf{1}$} & $\mathbf{2}$ & $\mathbf{3}$ & $\mathbf{4}$ & $\mathbf{5}$ \\
\hline 1 & $\begin{array}{l}\text { Social networking websites made contact with friends and family } \\
\text { easier. }\end{array}$ & $0 \%$ & $0 \%$ & $5 \%$ & $15 \%$ & $80 \%$ \\
\hline 2 & $\begin{array}{l}\text { The advancement of technology has affected human interaction } \\
\text { positively. }\end{array}$ & $0 \%$ & $0 \%$ & $15 \%$ & $15 \%$ & $60 \%$ \\
\hline 3 & $\begin{array}{l}\text { Communication via technology has made face-to-face } \\
\text { interactions decrease both in quality and quantity. }\end{array}$ & $0 \%$ & $10 \%$ & $15 \%$ & $50 \%$ & $25 \%$ \\
\hline 4 & $\begin{array}{l}\text { Parents are seriously concerned that their children are overusing } \\
\text { the Internet which affects their studies. }\end{array}$ & $5 \%$ & $5 \%$ & $10 \%$ & $60 \%$ & $20 \%$ \\
\hline
\end{tabular}

From Table 1, the analysis shows that $95 \%$ of the respondents either strongly agree or agree that social networking websites have made contacts with friends and family easier with $5 \%$ disagreeing. $60 \%$ of the students strongly agree that 
advancement of technology has affected human interaction positively while $15 \%$ agree and $15 \%$ disagree. Howevere, $10 \%$ strongly disagree.

Only $25 \%$ of the respondents strongly agree that technology has made face-to-face interactions decrease both in quality and quantity. However, majority of them (50\%) agree with the view while $15 \%$ disagree and $10 \%$ remain neutral.

$80 \%$ of the respondents either strongly agree or agree that parents are seriously concerned that their children are overusing the Internet which affects their studies. $10 \%$ of them disagree and $5 \%$ remain neutral while $5 \%$ strongly disagree.

The findings are supported by Urista, Dong and Day (2009), who stated that social network sites help fulfil communication needs and wants. It is a convenient method of communication and provides the ability to stay connected with friends and family, but on the other users' own rate and time.

\subsection{Types of Communication Technology used by peers}

Table 2.0 Types of Communication Technology used by peers

\begin{tabular}{|l|l|l|l|}
\hline NO & TYPES & $\begin{array}{l}\text { NUMBERS } \\
\text { (RESPONDENTS) }\end{array}$ & $\begin{array}{l}\text { PERCENTAGE OF RESPONDENTS USING } \\
\text { SOCIAL NETWORKING TO COMMUNICATE } \\
\text { WITH THEIR FRIENDS }\end{array}$ \\
\hline 1 & Facebook & 10 & $50 \%$ \\
\hline 2 & Twitter & 7 & $35 \%$ \\
\hline 3 & My Space & 3 & $15 \%$ \\
\hline 5 & E-mail & 18 & $90 \%$ \\
\hline 6 & Others & 16 & $80 \%$ \\
\hline
\end{tabular}

From Table 2, it could be seen that $90 \%$ of the respondents stated that they use e-mail for communication. $80 \%$ of them used the Internet, followed by Facebook (50\%). However, Twitter (35\%) and Myspace (15\%) were not popular among participants.

From the above findings, we can conclude that e-mail is the most popular form of communication among peers followed by Internet, Facebook, Twitter and Myspace respectively. However, a small percentage of the respondents use other forms than those. These findings are supported by Turrow (1999) who stated that e-mail is the primary Internet application and keeps both teens and adults coming back to the computer.

\subsection{How students view peer relationships in interpersonal understanding}

Table 3.0 Students view of Peer Relationship in Interpersonal Understanding

1 = strongly disagree 2 = Disagree $3=$ Neutral 4 = Agree 5 = Strongly Agree

\begin{tabular}{|c|c|c|c|c|c|c|}
\hline NO & RESEARCH STATEMENTS & \multicolumn{5}{|c|}{ SCALE (\%) } \\
\hline 1 & Peer relationships are important in interpersonal understanding. & $0 \%$ & $5 \%$ & $15 \%$ & $35 \%$ & $45 \%$ \\
\hline 2 & $\begin{array}{l}\text { College students are using technology more for chatting than } \\
\text { for discussing academic matters. }\end{array}$ & $35 \%$ & $5 \%$ & $10 \%$ & $30 \%$ & $20 \%$ \\
\hline 3 & Technology has helped to foster self-image among friends & $15 \%$ & $10 \%$ & $29 \%$ & $30 \%$ & $25 \%$ \\
\hline 4 & $\begin{array}{l}\text { Technology has contributed greatly to develop social skills in } \\
\text { communication }\end{array}$ & $10 \%$ & $0 \%$ & $15 \%$ & $35 \%$ & $40 \%$ \\
\hline 5 & $\begin{array}{l}\text { Cyber-crime such as cyberbullying is the negative effect of } \\
\text { technology }\end{array}$ & $10 \%$ & $15 \%$ & $15 \%$ & $35 \%$ & $25 \%$ \\
\hline 6 & $\begin{array}{l}\text { The Internet has become the ideal form of communication } \\
\text { among peers. }\end{array}$ & $5 \%$ & $5 \%$ & $10 \%$ & $20 \%$ & $60 \%$ \\
\hline 7 & $\begin{array}{l}\text { Students communicate more frequently with friends and family } \\
\text { via technology than they do in person. }\end{array}$ & $10 \%$ & $10 \%$ & $30 \%$ & $25 \%$ & $25 \%$ \\
\hline 8 & $\begin{array}{l}\text { Presence of technology while spending time with others affects } \\
\text { face-to-face interpersonal communication. }\end{array}$ & $0 \%$ & $0 \%$ & $25 \%$ & $50 \%$ & $25 \%$ \\
\hline 9 & $\begin{array}{l}\text { There is a degradation in the quality of peer conversations } \\
\text { when technology is present or being used. }\end{array}$ & $5 \%$ & $5 \%$ & $10 \%$ & $60 \%$ & $20 \%$ \\
\hline
\end{tabular}




\begin{tabular}{|l|l|l|l|l|}
\hline $0 \%$ & $20 \%$ & $10 \%$ & $50 \%$ & $20 \%$ \\
\hline
\end{tabular}

From the questionnaire, it could be seen that $45 \%$ of the respondents strongly agreed that peer relationships are very important in interpersonal understanding while $15 \%$ disagreed. $40 \%$ of them strongly agreed that technology has helped to develop social skills in communication while 10\% strongly disagreed. $30 \%$ of the respondents agreed that technology has helped to foster self-image among friends whereas $20 \%$ disagreed with $10 \%$ remaining neutral. $25 \%$ of them strongly agreed that cyberbullying is the negative effect of technology while 35\% agreed and $15 \%$ disagreed. $30 \%$ of the respondents agreed that they use technology more for chatting than for discussing academic matters while $35 \%$ of them strongly disagreed and $20 \%$ strongly agreed. However, majority of the respondents $(60 \%)$ strongly agreed that the Internet has become the ideal form of communication among themselves while $10 \%$ disagreed and $5 \%$ strongly disagreed.

The findings indicate that $25 \%$ of the respondents strongly agree that they communicate more frequently with their friends and family via technology than in person. Another $25 \%$ agree but $30 \%$ disagree with the view. The majority group consists of $20 \%$ either remain neutral or strongly disagree. $50 \%$ of the respondents agree and another $25 \%$ of them strongly agree that the presence of technology affect their face-to-face communication negatively while spending time with others while $25 \%$ of the participants disagree with the view.

$80 \%$ of the students either strongly agree or agree that there is degredation in the quality of their conversations with others when technology is present or being used. The remaining $10 \%$ disagree, $5 \%$ neutral and $5 \%$ strongly disagree respectively. Majority of the respondents (50\%) agree that it bothers them when their friend or family members use technology while having conversations with others. However $20 \%$ of them agree while $20-\%$ disagree and $10 \%$ remain neutral. None of them strongly agree. This is supported by Patchin \& Hinduja (2011).

Research conducted by Turrow (1999), indicated that teens agreed that after doing homework, use of e-mail and participating in chat rooms were their most frequent activities on the Internet. In conclusion, the majority of the students strongly agreed that the Internet is the ideal form of communication and that peer relationships are very important in interpersonal understanding. Besides, they also strongly agreed that technology has helped to develop social skills. However, the respondents strongly disagreed that technology is used more for chatting than for academic purposes. Most of them agreed that cyberbullying is the negative effect of technology and the positive effect is that it helps to foster selfesteem.

\subsection{How technology has affected their relationship with their peers}

From the interview conducted, the respondents revealed that they mainly used cell-phones and e-mails to communicate with their friends almost daily. Their reasons is that they are convinient i.e. mobile and cost-effective. Moreover, there is privacy.

They use Facebook, Twitter, Myspace, e-mail and the Internet to generate information for research as well as exchange views with their friends and family. However, it seems they spend more time to discuss personal matters and viewing video and less time for academic matters. Their opinion is that ICTs have contributed greatly towards promoting closer rapport among peers and relatives.

\section{Limitation}

This study analyzed only a group of college students from a Teacher Education Institute in Malaysia, for a specific period. If more educational institutions had participated, the results might have been different. There could have been more equal gender distribution. Compared to females who made up $70 \%$ of the sample, there were only $30 \%$ of males included in this sample. Only a small sample was used for this study. Future studies could use bigger sampling.

\section{Conclusion}

The findings show that the students' of the respective Teacher Education Institute potentially use e-mail, mobile phones and the Internet to communicate. They discuss academic matters such as project work and also private and confidential matters in personal life. Peers consider their relationship significant as that of their parents. They agree that technologies have helped to foster self-esteem, co-operation and interpersonal understanding.

However, they admit that technology has produced some negative effects, too, such as cyberbullying and aggression. This can be tarnish the image of individuals and create fear in the minds of the victims. Technologies are only tools to be used for communication. How they are used depends upon the users. They are useful if used for constructive purposes and harmful if used wrongly. With the advancement in ICTs, information collected, analyzed and communicated with increasing speed through dramatic innovations in information technology, rapid international co0nnections and massive technological connections across national boundaries.

Since ICT's can overcome phsycal and geographical barriers, and facilitate communication, they have the potential to promote closer peer relationships. If not for the advent of ICT's, educational and social development could not have attained the current level. Technologies (Hardware and Software) are tools to be used for constructive purposes. Unfortunately, they are misused by some for wrongeful deeds. For instance, cyberbullying can tarnish the image of the victims. 
Adolescence is a turbulent period in the process of phsycal, mental, emotional and social development. So, parents and teachers have to monitor their children's activities, especially in the area of electronic communication among friends. Whatever it is, technology has promoted interpersonal understanding among peers inspite of its drawbacks. Websites create new ways of communication with friends and family and also influence individuals' self-concept. Social networking sites also offer new and innovative ways to communicate with other individuals quickly and frequently.

Boyd and Ellison (2007) defined social network sites as public web-based services that allows users to develop a personel profile, identify other users ("friends") with whom they have a connection, read and react to the postings made by other users on the site, send and receive messages either privately or publicly. However, the other researchers like Espalage \& Swearer 92003), claim that peer group becomes established as a hierarchy whereby students use to dominate their peers as a means of gaining prestige, power and access to resources. Moreover, many respondents voiced their concerns that technology is diminishing society's ability to communicate face-to-face.

\section{Recommendations}

It is recommended that the students learn to use a wide range of ICTs. They could attend short in-service courses to upgrade their skills in computer application. They must maintain healthy peer relationships. Since they are students, they must use ICTs more for academic matters and spend less time for private conversations. They must not resort to misusing technologies for wrongful purposes such as cuber bullying and aggression. Adolescence is a turbulent period during which phsycal, mental, emotional and social development takes place. So, parents and teachers have to monitor their children's activities closely, especially, in the area of electronic communication among friends.

\section{REFERENCES}

[1] Allen, J.P., \& Antonishak, J. (2008). Adolescent peer influences: Beyond the dark side. In M.J. Prinstein \& K.A.

Dodge (Eds.). Understanding peer influence in children and adolescents (pp. 141-1600. New York: Guilford.

[2] Archer, J., \& Coyne, S.M. (2005). An integrated review of indirect, relational and social aggression.

Personality and Social Psychology Review, 9, 212-230.

[3] Baker, L.R., \& Oswald, D.L. (2010). Shyness and online social networking services. Journal of Social \& Personal Relationship, 27(7), 873-889.

[4] Basinger, K.S, Gibbs, J.C., \& Fuller, D. (1995). Context and the measurement of moral judgement. International Journal of Behavioral Development, 18, 537-556.

[5] Baym, N.K., Zhang, Y.B., \& Lin, M. (2004). Social interactions across media. New Media \& Society, 6(3), 299318.

[6] Berndt, T.J., Laychak, A.E., \& Park, K. (1990). Friends' influence on adolescents' academic achievement motivation: An experimental study. Journal of Educational Psychology, 82, 664-670.

[7] Bjorkqvist, K., Lagerspetz, K. \& Kaukiainen, A. (1992). "Do girls manipulate and boys fight? Developmental trends in regard to direct and indirect agression". Aggressive Behavior, 18, 117-127.

[8] Boyd, D.M. \& Ellison, N.B. (2009). Social Network Sites: Definition, history and scholarship. Journal of Computer Mediated Communication, 13, 210-230.

[9] Brown, B.B. (1990). Peer groups. In S. Feldman \& G. Elliot (Eds.), At the threshold: The developing adolescent (pp. 171-196). Cambridge, MA: Harvard University Press.

[10] Brown, B. (2011). Popularity in peer group perspective: The role of status in adol Bscent peer systemss. In A.H.N. Cillessen, D. Schwartz, \& L.Mayeux (Eds.), Popularity in the peer system (pp.165-192). New York: Guilford.

[11] Brown, B.B., Bakken, J.P., Ameringer., S.W., \& Mahon, S.D. (2008). A comprehensive conceptualization of the peer influence process in adolescence. In M.J. Prinstein \& K.A. Dodge (Eds.), Understanding peer influence in children and adolescents (pp. 17-44). New York: Guilford.

[12] Coley, R., Cradler, J. \& Engel, P. (1997). Computers and classrooms: The status of technology in US schools. Princeton, NJ: Policy Information Centre, Education Support System.

[13] Crook, C. (1994). Computers and the colloborative experience of learning. London: Routledge.

[14] Crosnoe, R. (2011). Fitting in, standing out: Navigating the social challenge of high school to get an education. Cambridge, England: Cambridge University Press. 
[15] Dishion, T.J., Piehler, T.F., \& Myers,M.W. (2008). Dynamics and ecology of adolescent peer influence. In M.J. Preinstein \& K.A. Dodge (Eds.), Understanding peer influence in children and adolescents (pp. 72-93). New York: Guileford.

[16] Dooley, J.J., Pyzalski, J. \& Cross, D. (2009). Cyberbullying versus face-to-face bullying: A theoritical and conceptual review. Journal of Psychology, 217, 182-188.

[17] Ellison, N.B., Steinfield, C., \& Lampe, C. (2007). The benefits of Facebook "friends": Social capital and college students' use of online social network sites. Journal of Computer-Mediated Communication, 12 , 1143-1168.

[18] Erwin, P. (1993). Friendship and peer relations in children. Chicester, England: Wiley.

[19] Espelage, D.L., \& Swearer, S.M. (2003). Research on school bullying and victimization: What have we learnt and where do we go from here? School Psychology Review, 32(3), 365-383.

[20] Freedman, S.G. (1990). Small victories: The real world of a teacher, her student, and their high school. New York: Harper \& Row.

[21] Gottman, J.M. (1986). The world of coordinated play: Same and cross-sex friendship in young children. In J.M. Gottman, \& J.G. Parker (Eds.), Conversations of friends: Speculations on affective development (pp. 139-191). Cambridge, England: Cambridge University Press.

[21] Greenhow, C., Robelia, B., \& Hughes, J.E. (2009). Web 2.0 and classroom research. What path should we take now? Educational Researcher, 38, 246-259.

[22] Gross, E.F., Juvonen, J., \& Gable, S.L. (2002). Internet use and well-being in adolescence. Journal of Social Issues, 58, 75-90.

[23] Hawkins, J., Sheingold, K., Gearhart, M. \& Berger, C. (1982). Microcomputers in schools: Impact on the social life of elementary classroom. Journal of Applied Development Psychology, 3, 361-373.

[24] Jarvela, S., Bonk, C.J., Lehtinen, E. \& Lehti, S. (1999). A theoritical analysis of social interactions in computer-based learning environments: Evidence for reciprocal understandings. Journal of Educational Computing Research, 21(3), 359-384.

[25] Koschmann, T. (1996). Paradigm shifts and instructional technology: An introduction. In T. Koschmann (Ed.) CSCL: Theory and practice of an emerging paradigm (pp. 1-23). Machwah, NJ: Lawrence Erlbaum.

[26] Koschmann, T., Hall, R., \& Miyake, N. (2002). CSCL 2.: Carrying forward the conversation. Mahwah, NJ: Lawrence Erlbaum.

[27] Kowalski, R.M., \& Limber, S.P. (2007). Electronic bullying among middle school students. Journal of Adolescent Health, 41, S22-S30.

[28] Kubey, R.W., Lavin, M.J., \& Barrow, J.R. (2001). Internet use and collegiate academic performance decrement: Early findings. Journal of Communication, 366-382.

[29] Kumpulainen, K. \& Wray, D. (2002). Classroom interaction and social learning. London: Routledge.

[30] Larson, R.W., \& Brown, J.R. (2007). Emotional development in adolescence. What can be learned from a high school theatre program? Child Development, 78, 1083-1099.

[31] Laursen, B., Bukowski, W.M., Aunola, K. \& Nurmi, J.E. (2007). Friendship moderates prospective associations between social isolation and adjustment problems in young children. Child Development, 78, 1395-1404.

[32] Lehtinen, E. (2002). Developing models for distributed problem based learning: theoritical and methodological reflection. Distance Education, 23(1), 109-117.

[33] Lehtinen, E., Hakkarainen, K. \& Lipponen, L., Rahikainen, M. \& Muukkonen, H. (1999). Computer supported collaborative learning: A review. The J.H.G.I. Giesbers Reports on Education, No 10. The Neitherlands: 
University of Nijmegen.

[34] Lenhart, A., Purcell, L. Smith, A., \& Zickuhr, K. (2010). Social media and young adults. Pew internet and american life project. Retreived June 2011, 2016 from http:// www.pewinternet.org/Reports/2010/SocialMedia-and-Young-Adults.aspx

[35] Lloyd, J.M., Dean, L.A., \& Cooper, D.L. (2007). Students' technology use and its effects on peer relationships, academic involvement and healthy lifestyles. NASPA Journal, (44)3, 481-495.

[36] Levitt,M.J., Guacci-Franco, N., \& Levitt J.L. (1993). Convoys of social support in childhood and early adolescence: Structure and function. Developmental Phsychology, 29, 811-818.

[37] Parks, C.P., (1995). Gang behavior in schools: Reality or myth? Educational Psychology Review, 7, 41-68.

[38] Patrick, H., Andermann, L.H., \& Ryan, A.M. (2002). Social motivationand the classroomsocial environment.In C. Midgley (Ed.), Goals, goal structures, and patterns of adaptive learning (pp.85-108). Mahwah, NJ: Erlbaum.

[39] Paul, S., Smith, P.K., \& Blumberg, H.H. (2012). Revisiting cyberbullying in schools using the quality circle approach. School Psychology International, 33(5), 492-504.

[40] Patchin, J.W., \& Hinduja, S. (2010). Cyberbullying and self-esteem. Journal of School Health. 80, 614-21.

[41] Pellegrini, A.D., \& Long, J.D. (2002). A longitudinal study of bullying, dominance and victimization during the transition from primary school through secondary school. British Journal of Development Psychology, 20, 259-280.

[42] Pempek, T.A., Yermolayeva, Y.A., Calvert, S.L. (2009). College students' social networking experiences on facebook. Journal of Applied Development Psychology, 30(3), 227-238.

[43] Pogrow, S. (1996). Using computers and other visual technology to combine process and content. In A. Costa \& R. Liebman (Eds.), When process is content: Toward renaissance learning (pp. 98-116). Thousand Oaks, CA: Corwin Press.

[44] Quan-Haase, A., \& Young, A.L. (2010). Uses and gratifications of social media: A comparison of Facebook and Instant Messaging. Bulletin of Science, Technology \& Society, 30 (5), 350-361.

[45] Rose, A.J. (2002). Co-rumination in the friendship of girls and boys. Child Development, 73, 1830-1843.

[46] Salamon., G. (1994). Differences in patterns: Studying computer enhanced learning environments. In S. Vosniadou, E. De Corte \& H. Mandl (Eds.) Technology-based learning environments: Psychological and educational foundations (pp. 79-85). NATO ASI Series F: Computer and System Science, Vol. 137. Berlin: Springer.

[47] Shariff, S. (2008). Cyber-bullying: Issues and solutions for the school, the classroom and the home. London: Routledge.

[48] Sharp, S., Thompson, D., \& Arora, T. (2000). How long before it hurts? An investigation into long-term bullying. School Psychology International, 21,(1), 37-46.

[49] Smith, P.K., Mahdavi, J., Carvalho, M., Fisher, S.Russell, S., \& Tippett, N. (2008). Cyberbullying: Its nature and impact in secondary school pupils. Journal of Child Psychology ad Psychiatry, 49, 376-385.

[50] Spears, B., Slee, P., Owens, L., \& Johnson, B.(2009). Behind the scenes and screens: Insights into the human dimension of covert and cyberbullying. Journal of Psychology, 217, 189-196.

[51] Steinberg, L. (1996). Risk taking in adolescence. Current Directions in Psychological Science, 16, 55-59.

[52] Steinkuehler, C.A., Derry, S.J., Hmelo-Silver, C.E. \& DelMarcelle, M. (2002). Cracking the resource nut with distributed problem-based learning in secondary teacher education. Distance Education, 23(1), 23-29.

[53] Tufekci, Z. (2008). Grooming, gossip, facebook and myspace. Information, Communication \& Society, 11(4), 544-564. 
[54] Turkle, S. (1984). The Second Self. New York: Simon \& Schuster.

[55] Turow, J. (1999). The internet and the family: The view from parents, the view from the press. Philadelphia, PA: Annenberg Public Policy Centre of the University of Pennsylvania.

[56] Urdan, T.C., \& Maher,M.L. (1995). Beyond a two-goal theory of motivation and Achievement: A case for social goals. Review of Educational Research, 65, 213-243.

[57] Urista, M.A., Dong, Q., \& Day, K.D. (2009). Explaining why young adults use myspace and facebook through uses and gratification theory. Human Communication, 12(2), 215-229.

[58] Valkenburg, P.M., \& Peter, J. (2009). Social concequencesog the Internet for adolescents: A decade of research. Current Directions in Social Science, 18, 1-5.

[59] Vossekuil, B., Fein, R., Borum, R., \& Modezeleski, W. (2002). The final report and findings of the safe school initiative: Implications for the prevention of school attacks in the United States. U.S. Secret Service and U.S. Department of Education, Washington D.C.

[60] Wentzel, K.R. (2009). Peers and academic functioning at schools. In K.H. Rubin, W.M. Bukowski, \& B. Laursen (Eds.), Handbook of peer interaction, relationships, and groups (pp. 531-547), New York: Guilford.

[61] Willard, N.E. (2007). Cyberbullying and cyberthreats: Responding to the challenge of online social aggression, threats and distress. Champaign, IL: Research Press.

[62] Wolak, J., Mitchell, K.J., \& Finkelhor, D. (2007). Does online harassment constitute bullying? An exploration of online harassment by known peers and online-only contacts. Journal of Adolescent Health, 41, 51-58.

\section{Biography}

Ramesh Sathappan was born in Pontian, Johor. He obtained his Bachelor degree in Management Technology from Universiti Teknologi Malaysia in 1999. He earned his Master's degree in Teaching English as a Second Language (TESL) from Universiti Teknologi Malaysia in 2010. Currently he is a lecturer in a Teacher Education Institute in Malaysia teaching Education subjects for undergraduates. His research interest areas are educational psychology, educational technology and curriculum change. 